Yuliia Humenna,

Ph.D, Sumy State University, Ukraine

(iD) ORCID ID, 0000-0001-5309-6016

email: y.humenna@biem.sumdu.edu.ua

Ihor Martsovenko,

Ph.D., Sumy Regional Cardiology Clinic, Ukraine

iD ORCID ID, 0000-0001-8197-4066

email: cardiosumy_17@i.ua

Paulína Srovnalíková,

Ph.D., MBA, University of Alexander Dubchek in Trencin, Slovakia

(iD) ORCID ID, 0000-0003-4979-5505

email: daes.srovnalikova@gmail.com

Correspondence author: y.humenna@biem.sumdu.edu.ua

\title{
HEALTH CARE REFORM IN UKRAINE: PUBLIC-PRIVATE PARTNERSHIP ISSUES
}

Abstract. This article is devoted to the study of the peculiarities of the public-private partnership implementation as the key form of investing financial resources in the sphere of medical services in Ukraine. The purpose of the investigation is studying issues of public-private partnership in the financing of the medical sector of Ukraine on the example of the Sumy Regional Clinical Cardiology Dispensary. This article examines modern concepts and publicprivate partnership's models in the field of health care and the features of their practical implementation. The legislative base of public-private partnership within the health care system of Ukraine is analysed. Methodological support of the research includes the use of the following methods: system analysis, synthesis and scientific abstraction, structurallogical, comparative and statistical analysis, and retrospective method. The results of the study allowed: determine the subjective and object components of public-private partnership; analyse foreign experience in the formation of models combining the functions that are directed to the private partner by government agencies substantiate features of introduction of partnership in the conditions of medical reform; study the practice of implementing partnership projects for health care branch in Ukraine; provide medical and social justification for increasing the quality of medical care for patients with acute coronary syndrome on the basis of the model of public-private partnership; identify barriers while the implementation of public-private partnerships in the field of health care at the present stage of development of the medical services sphere in Ukraine; improve the public-private partnership model based on a joint venture agreement between the public unity service and the private entity in order to improve the quality of emergency care for patients with acute coronary conditions. The paper states that when using the capabilities of the mechanism of public-private partnership, by involving in the provision of quality medical care material and technical and human resources of the private medical enterprise «Alfa-Medica» and by providing invasive medical care to patients with acute cardiac syndrome in 2015-2019 the reduction in mortality and disability has been achieved. The study provides the recommendations for taking into account while creating the strategy for the public-private partnership projects implementation in the field of health care in Ukraine, both state and regional interests in solving medical and social problems through the relevant programs.

Keywords: public-private partnership, health care reform, public partner, private partner, acute cardiac pathology, coronary heart disease.

Introduction. In the context of socio-economic changes in Ukraine, the processes of health care reform are accompanied by an unresolved problem of state regulation the investment support for the development of the medical sector. The key task of health care reform is to build health care model to ensure equal and fair access of the people to the necessary medical services, their high quality and

Cite as: Humenna, Yu., Martsovenko, I., \& Srovnalikova, P. (2021). Health Care Reform In Ukraine: Public-Private Partnership Issues. Health Economics and Management Review, 3, 79-88. http://doi.org/10.21272/hem.2021.3-07

79 
efficiency while maintaining the socially accepted amount of state guarantees (Law of Ukraine, 2017; Order, 2013).

The World Health Organization's (WHO) Annual Population Health Survey highlights new pressing issues that need to be addressed globally. Such problems include: the emergence of new diseases and their rapid spread due to increasing population mobility, population aging, funding problems caused by limited resources and rising costs of services, increased demands on the availability and quality of health care (Musgrove, 1996).

Today, no country in the world can finance health care solely due to public funds, additional private investment is needed. The level of state regulation of health care in Ukraine today does not meet the new conditions and requires the formation of a qualitatively new management system. The main direction of increasing the effective functioning of health care system is the development of partnership between the state and business. It allows attract additional financing to the public sector of the economy, primarily investment.

The needs of the population in modern and high quality medical services are growing faster than the available financial capacity of the state budget, even in developed economies. Therefore, public-private partnership (PPP) in the financing of the medical sector is gaining popularity in the world (Kyiv Regional Target Program, 2017).

In domestic medical practice, PPP in health care field is understood as the search for an investor to purchase equipment for a medical institution. PPP as a form of investing in relevant projects acts as a charity rather than a partnership. Therefore, there is a need to stimulate business partnerships for implementing granting preferences, depending on the investing in the development of the national health care system, in particular - in its logistical re-equipment (Brailovsky, 2013; Bezbach, 2011).

Insufficient funding for health care, lack of modern equipment for providing patients with services based on new diagnostic and treatment methods within the evidence-based medicine and allow reduce significantly mortality and disability in acute cardiac pathology, the search for new opportunities to attract material and human resources base of private medical institutions to provide quality medical care for patients with cardiac pathology, - all these problematic aspects formed the preconditions for this study.

Literature Review. Numerous works of scientists (Brailovsky, 2013; Bezbach, 2011; Musgrove, 1996; Vynnytsky et al., 2008; Law of Ukraine, 2010; Law of Ukraine, 2017) are devoted to the aspects of financing investment projects in the medical field, in particular on the terms of PPP. Key tasks of the PPP in the health care field are: improving the quality of medical services; ensuring the efficient use of budget funds; ensuring higher efficiency of activities through the involvement of competencies and experience of a private partner, etc. (Guidelines, 2018; Vynnytsky et al., 2008).

The legal framework on PPP in the health care field in Ukraine is represented by a wide range of legal acts, which include:

- «Law of Ukraine «On Public-Private Partnership», № 2404-VI, dated 01.07.2010;

- Order of the Cabinet of Ministers of Ukraine «On approval of the Concept of public-private partnership in Ukraine for 2013-2018» № 739, dated 14.08.2013;

- Resolution of the Cabinet of Ministers of Ukraine «On approval of the Procedure for providing a private partner to a public partner with information on the implementation of an agreement concluded within the framework of a public-private partnership» № 81, dated 09.02.2011;

- Resolution of the Cabinet of Ministers of Ukraine «On Approval of the Procedure for Providing State Support to Public-Private Partnerships» № 279, dated 17.03.2011;

- Resolution of the Cabinet of Ministers of Ukraine «On approval of the Procedure for replacement of a private partner under an agreement concluded within the framework of a public-private partnership» № 298, dated 26.04.2017; 
- Order of the Ministry of Economic Development and Trade of Ukraine «Some issues of analysis of the effectiveness of public-private partnership» № 255, dated 27.02.2012 (Guidelines, 2018; Resolution, 2011).

The analysis of the legal regulation of PPP implementation in the health care field allowed determine the general and specific requirements for the PPP projects implementation. The general requirements of the legislation on the implementation of PPP projects, which are typical for projects in any field, namely in the health care field, include: participation of relevant state bodies and local governments as state partners; the existence of a PPP agreement as a basis for cooperation between public and private partners; implementation of competitive issues in defining the private partner; private investment in partnership is obligatory; the period of PPP validity is from 5 to 50 years (Guidelines, 2018; Vynnytsky et al., 2008).

Specific features of PPP projects in the health care field include:

- prohibition for reducing the network of state and municipal health care institutions - $\mathrm{HCl}$ (the transfer of the relevant facility to a private partner should not result in the decresing of the ability to provide medical services for state or municipal $\mathrm{HCls}$ );

- specific structure of the subjects, namely the state partner should be represented either at the level of the Ministry of Health of Ukraine (for objects of state property) or local governments (for objects of communal property);

- the necessity to balance the social with commercial component of the project (return on investment of a private partner is usually carried out through the providing of paid services);

- constitutional restrictions for paid services in state and municipal $\mathrm{HCls}$, the exhaustiveness of the list of paid services provided at state and municipal $\mathrm{CHCs}$ and higher medical educational institutions (Guidelines, 2018; Law of Ukraine, 1999).

Methodology and research methods. The methodological basis of the investigation includes the use of the following methods: the method of systematic analysis (while systematization of literature sources and regulatory framework in the context of PPP regulation), synthesis and scientific abstraction, structurallogical, comparative (while comparing models of cooperation of public institutions and private investors) and statistical analysis (while analysing the incidence rates of DCS and ACS within the population of Sumy region; indicators of interventional care for patients, including acute myocardial infarction for 2015-2019 within coronary angiography and stenting), retrospective methods.

Results. Improving funding mechanisms in the form of PPP in the context of investing in the medical sector involves a step-by-step study of the following aspects:

- subject and object components of PPP;

- -foreign experience of PPP models of a combination of functions which are transferred to the private partner by state institutions;

- features of PPP implementation in the conditions of medical reform;

- practical experience in implementing PPP projects in the health care field in Ukraine.

The conceptual framework of PPP in the medical field includes object and subject components. According to the second part of Article 7 of the Law of Ukraine «On Public-Private Partnership» objects of public-private partnership are: existing, in particular reproducible (by reconstruction, modernization, technical re-equipment) objects that are in state or communal ownership or belong to The Autonomous Republic of Crimea, including subsoil areas; objects created or acquired as a result of the implementation of the agreement concluded within the PPT. PPPs in the health care field are public and private partners, their functions and key areas of cooperation are shown in Table 1. 
Table 1. Cooperation between public and private health partners

\begin{tabular}{ll}
\hline & \multicolumn{1}{c}{ Public partners } \\
\hline $\begin{array}{l}\text { The subject of } \\
\text { the partnership }\end{array}$ & $\begin{array}{l}\text { local communities - relevent state bodies (for Legal individuals, except for state and public } \\
\text { example, the Ministry of Health of Ukraine) and enterprises, or sole proprietor } \\
\text { local authorities }\end{array}$ \\
$\begin{array}{ll}\text { Key functions } \\
\text { and directions of }\end{array}$ \\
$\begin{array}{ll}\text { To give the private partner the right to design, They are selected based on the results of the } \\
\text { couperation }\end{array}$ & $\begin{array}{l}\text { separate rooms) and further management of the reconstruction of health care buildings (or } \\
\text { object (with the right, or without the right to separate rooms), purchase of equipment and } \\
\text { provide medical services); access to facility management (combination may differ } \\
\text { diagnostics and medical equipment, its service depending on the PPP model) accompanied with } \\
\text { (with the right or without the right to provide the return of PPP project into state ownership } \\
\text { medical services) }\end{array}$ \\
& $\begin{array}{l}\text { after the expiration of the PPP term (from } 5 \text { to } 50 \\
\text { years) }\end{array}$ \\
\hline
\end{tabular}

Sources: developed by the authors.

According to the Law «On Public-Private Partnership» and «Guidelines for the implementation of public-private partnership projects in the field of health care» as the public partner may act (current legislation allows several entities participate for the public partnership):

- for state-owned objects: the state of Ukraine, represented by an authorized central executive body, which manages a potential PPP facility (usually the Ministry of Health or another central executive body, which may be a departmental hospital);

- for objects of municipal property: local community represented by the relevant local authorities.

The degree of involvement of the hospital in the contractual relations of the PPP depends on the organizational form of the institution:

- for budgetary institutions: the possibility of participation in the PPP agreement is not provided (in fact, the budgetary institution, namely its separate property, acts as an object and not as a subject of such relations);

- for autonomous hospitals: by decision of the state partner, a state-owned enterprise, municipal enterprise or business association, $100 \%$ of the authorized capital of which belongs to the state or local community, may participate in the PPP contract on the side of the respective state partner (Guidelines, 2018; Law, 2017).

The state partner is liable for the obligations of such enterprise or company according with the contract concluded under the PPP.

Ensuring the interaction of the state and business is one of the priority conditions for the balanced development of social relations, while the world experience shows that the variations of the models of such cooperation are practically not limited. Nevertheless, in Ukraine the tools of legal registration of partnership relations between the public and private partner are only at the stage of their formation (Guidelines, 2018; Ministry of Infrastructure of Ukraine, n.d.).

In Europe, the DBFO model has been widely used in recent years, according to which a private partner finds financing, builds or reconstructs a facility, puts it into operation, and then is responsible for the technical condition of buildings. 
Table 2. Models of a combination of functions that are delegated to a private partner Model The essence of the model

Build-Operate-Transfer «Construction-Management-Transfer»: a private partner responsible for construction (BOT) and operation (mainly on property rights) for a specified period, after which the object is transferred to the state.

Build-Transfer-Operate «Construction-Transfer-Management»: a private partner builds an object, which is

Build-Own-Operate

Buy-Build-Operate transferred to the state (grantor) ownership immediately after finishing the construction, after it is transferred to the operation of the concessionaire.

«Construction-Ownership-Management»: a private partner builds a facility and carries out further operation, owning it on the property rights, the validity of which is not limited. «Purchase-Construction - Operation»: transfer of a state or public property to a private entity on the terms of a contract, according to which such a facility should be modernized and operated within the period.

Design-Build-Finance- «Development - Construction - Financing - Management»: a private company develops Operate (DBFO) and builds a medical institution according to the requirements and standards approved by the authorities, finances expenditures, manages the medical institution.

Design-Build-Finance- «Development - Construction - Financing - Maintenance»: provides the additional nonMaintain (DBFM) clinical services, including individual (cleaning, logistics, security, etc.).

Sources: developed by the authors on the basis of (U.S. Agency, 2021).

The advantages of implementing PPP in the health care field are:

- additional funding as the possibility of attracting funds from private investors for the development of state and municipal health care facilities;

- ensuring the preservation of property in communal/state ownership (direct ban on privatization);

- transfer of newly created and purchased objects within the PPP to state / municipal ownership;

- an opportunity to improve the quality of medical services for the population (Guidelines, 2018).

Since the health care system of Ukraine is accompanied by medical reform, the structuring of any PPP project in this direction should take into account the following aspects:

- processes of autonomy of health care institutions;

- planned transition to the financing of medical services depending on the types of medical care;

- processes of hospital districts' formation and some other aspects (Guidelines, 2018; Law of Ukraine, 2010).

Today, the reform of the health care financing system is the basis for creating the preconditions for positive changes in the field of health care. Next, comprehensive measures need to be taken to upgrade the logistics of hospitals. The tariff for medical services does not cover the costs of purchasing medical equipment, and the allocation of such funds from local budgets is difficult to predict - all these factors form the preconditions for the maximum expansion of the available tools for attracting alternatives. One such source is the funds of a private investor that can be raised within the PPP. The prospects for the introduction of PPP in the context of health care reform are that the program of medical guarantees will allow a clear separation of medical services covered by state guarantees and paid services, through which the private partner will be able to compensate for the investment; Carrying out the autonomy of health care institutions $(\mathrm{HCl})$ will give an opportunity to introduce such forms of PPP as concession and joint activity and will give the opportunity to automated institutions to become a participant of PPP on the side of the state partner; «Local incentive» programs (at the expense of local budgets) can be the source of compensation for the costs of the investor to encourage him to participate in PPP projects.

The introduction of investment in the medical sector on the terms of PPP in Ukraine involves a preliminary analysis of the current practical use of this form of health care financing in Ukraine. Thus, projects that can be considered as examples of PPP in the health care field in Ukraine are the Ukrainian 
Tomotherapy Center on the basis of Kirovograd Regional Oncology Center, Sumy Regional Blood Service Center, Clinical Scientific and Methodological Center for X-ray Doscular Medicine on the basis of the University Clinic of Odessa National Medical University , Novo Medical Innovation Center on the basis of Lviv Municipal City Children 's Clinical Hospital.

For the Ukrainian tomotherapy center on the basis of the Kirovohrad regional oncological dispensary PPP is realized on the following conditions: the contribution of the public partner - the area of the center is 1000 sq.m.m., the contribution of a private partner is highly specialized equipment, including linear accelerator, and free treatment of 50 patients per year. Also, in this aspect, the Sumy Regional Blood Service Center deserves attention, where the introduction of PPP involves the creation of a joint venture by $25 \%$ with the participation of local governments and $75 \%$ with the participation of a private investor LLC «Biopharma». The benefit of the private investor LLC «Biopharma» is to gain access to the purchase of blood components, which the company uses in its main activities for the manufacture of blood products.

In the Clinical Scientific and Methodological Center of X-ray Endovascular Medicine on the basis of the University Clinic of Odessa National Medical University PPP is carried out with the participation of a private partner in the form of purchase of highly specialized equipment, including angiogram.

For the Novo Medical Innovation Center on the basis of the Lviv Municipal City Children's Clinical Hospital, a private partner provides for the renovation of the building and providing highly specialized equipment. It is worth mentioning about such category of projects that position themselves as examples of PPPs in the field of health care in Ukraine.

They include:

- construction and opening of the Diagnostic Center on the territory of Boryspil Central District Hospital (300 sq.m. building, completed to the main building), ScanDiagnostics LLC is a private partner, and the project was implemented as a private initiative;

- a project to establish a Center for Minimally Invasive Surgery on the third floor of the surgical building of the Truskavets City Hospital (on the terms of joint activities), which is currently being prepared for the announcement of the competition;

- IFC project to merge several old hospitals into new one which is under development.

The analysis of the use of PPP as a form of investment in the medical sector of Ukraine shows the practical experience for domestic economic entities and government agencies in this area. In order to further improve the financial support of medical services, in particular in the treatment of cardiovascular problems and vascular diseases, which include diseases of the circulatory system (DCS) and acute coronary syndrome (ACS), based on the use of PPP-form of investment, there should be analyzed the state of morbidity and mortality of the population of Ukraine and Sumy region as a result of these diseases.

Thus, diseases of the circulatory system in recent decades are the cause of death of the population of developed countries, including Ukraine. In 2019, the mortality rate from DSC was $67.0 \%$ of the total mortality of the population. Mortality rates from these diseases in Ukraine are 2-4 times higher than in Western European countries, the United States, Canada, Australia, and so far there is a tendency to increase mortality. In the structure of mortality from cardiovascular diseases, coronary heart disease accounts for $60 \%$ of men and $40 \%$ of women.

Diseases of the circulatory system are the most common among the population of Ukraine that cause death. These pathologies are registered in $57.5 \%$ of the population of Ukraine, which is 26.4 million patients, among them 9.6 million people are of working age. From these diseases about 15 people for every 10 thousand adult population of Ukraine become disabled every year, they are the cause of death of 160 thousand people a year.

The prevalence of coronary heart disease (CHD) in Ukraine among people of working age in 2019 was 9.7 thousand per 100 thousand of population, the prevalence of coronary heart disease among adults in 2019 in Ukraine was 24 thousand per 100 thousand population. 
According to the Ministry of Health of Ukraine in 2019, 50,744 cases of acute and recurrent myocardial infarction (ARMI) were detected among the adult population (135.7 cases per 100,000 population). Also, morbidity and mortality rates from this disease are high in almost all industrialized countries. According to the US National Registry, more than 5 million people in the United States suffer from coronary heart disease (CHD). For men under the age of 35 , it is the leading cause of death, and for those over the age of 45 , coronary heart disease is the leading cause of death for both men and women. In England and Wales, more than $30 \%$ of male deaths and $22 \%$ of female deaths are due to coronary heart disease. CHD, like any chronic disease, is characterized by periods of stable course and exacerbations. It is during the exacerbation of coronary heart disease significantly increases the risk of death, which often occurs in the first hours after the onset of clinical manifestations. The period of exacerbation of coronary heart disease is currently referred to as acute coronary syndrome.

ACS is a clinical-electrocardiographic symptom complex that develops within acute mismatch of myocardial oxygen demand and its delivery due to thrombotic obstruction (95\% of cases) or persistent spasm (up to $5 \%$ of cases) to the coronary artery. Advances in the treatment of severe manifestations of CHD - myocardial infarction are well known, the mortality of which in hospitals decreased in the middle of the century from $40-50$ to $10 \%$, and now in some institutions even up to $5 \%$.

It is worth saying that more than half of people with myocardial infarction die within the first hour of the disease that is then medical care is not yet provided for these people. It should also be noted that in about a quarter of patients with myocardial infarction, clinical manifestations may be so asymptomatic that they are ignored, although they have the same unfavorable prognosis as patients with a detailed clinical picture of myocardial infarction have. This may to some extent explain the fact that CHD often manifests itself only in the form of sudden death. Recently, new data on the peculiarities of ACS have appeared, new drugs and methods of treatment have been introduced in the clinic. It could significantly improve the prognosis. At the same time, despite modern approaches to the treatment of patients, the mortality rate in ACS remains high. A necessary condition for improving the survival of patients with exacerbation of CHD is timely diagnosis and the correct choice of treatment tactics in the first minutes and hours of the disease.

The state policy of providing and regulating the healthcare industry is aimed at ensuring the health of the population, reducing mortality from diseases of the cardiovascular system. According to the results of the monitoring of the Ministry of Health of Ukraine (Ministry, 2021), Sumy region for the last decade is a region with a high level of depopulation. The number of people with diseases of the circulatory system in Sumy region has reached 600 thousand people (in Ukraine - 25.8 million),more than $60 \%$ is adult population, among them $27 \%$ - have hypertension.

The prevalence of DSC among the population ranked first in the structure of the overall prevalence of diseases and amounted to 57,459.63 cases per 100 thousand people. Given this, the treatment of this group of pathologies, as well as the development of preventive measures to reduce morbidity and mortality, is one of the priorities of the health care system.

Table 3. Incidence rates of DCS and ACS within the population of Sumy region (per 100 thousand population) for the period 2015-2019, number of people

\begin{tabular}{lccccc}
\hline & \multicolumn{4}{c}{ per 100 thousand population } \\
& $\mathbf{2 0 1 5}$ & $\mathbf{2 0 1 6}$ & $\mathbf{2 0 1 7}$ & $\mathbf{2 0 1 8}$ & $\mathbf{2 0 1 9}$ \\
\hline Number of recorded cases of DCS & 4972,6 & 5077,0 & 4940,5 & 4586,5 & 4439,9 \\
The number of recorded cases of & 129,91 & 134,40 & 140,26 & 135,80 & 132,91 \\
ARMI & & & & & \\
Including focal (transmural) diseases & 80,76 & 85,94 & 83,85 & 85,50 & 74,25 \\
\hline
\end{tabular}

Sources: developed by the authors. 
As Table 1 shows, over the last five years in the region there is a tendency to reduce the incidence of DCS from 4,972.6 cases per 100,000 population in 2015 to $4,439.9$ cases in 2019. Moreover, there is a tendency to decrease the levels of acute and recurrent myocardial infarction, including large-focal infarcts (transmural) from 80,76 cases per 100 thousand population in 2015 to 74.25 cases in 2019.

Let's analyze the practical use of public-private partnership while providing the medical services in Sumy region, in particular - while providing interventional medical care for patients with ACS on the basis of public-private partnership agreement between Sumy Regional Cardiology Dispensary and LLC «AlfaMedica» for the period 2015-2019 years.

Current requirements for the providing of cardiac care for patients with acute cardiac pathology require immediate coronary angiography and primary stenting of cardiac vessels that should be performed during 7 days a week. However, there is no condition for their holding in the Municipal Institution of Sumy Regional Council «Sumy Regional Cardiology Dispensary» with an annual need of up to 1,200 patients with acute myocardial infarction and more than 5,000 patients with angina, excluding patients with stable angina, in particular - there are 19,000 persons of working age.

In 2013, the Director of the Department of Reforms and Development of Medical Care of the Ministry of Health of Ukraine approved the «Regional Action Plan for the establishment of cardiac surgery and reperfusion centers for patients with acute cardiovascular and cerebrovascular pathology in Sumy region for 2013-2017».

Reperfusion care for cardiac patients of the region (emergency) since 2013 is provided by Alfa-Medica LLC, which leases premises in Sumy Regional Cardiology Dispensary on the basis of a public-private partnership agreement, but only $10 \%$ of needy patients receive it - the company's capabilities are limited.

During 2015-2017, all interventional interventions for patients with ACS were performed exclusively on the equipment of Alfa-Medica LLC (Tables 4 and 5), as only this medical institution had a single angiograph in Sumy region.

Table 4. Interventional care for patients, including acute myocardial infarction for 2015-2019 (coronary angiography)

\begin{tabular}{lllllr}
\hline \multicolumn{7}{c}{ Coronary angiography } \\
\hline Total & $\mathbf{2 0 1 5}$ & $\mathbf{2 0 1 6}$ & $\mathbf{2 0 1 7}$ & $\mathbf{2 0 1 8}$ & $\mathbf{2 0 1 9}$ \\
Alfa-Medica LLC & 74 & 284 & 381 & 578 & 929 \\
\hline
\end{tabular}

Sources: developed by the authors.

Table 5. Intervention care for patients, including acute myocardial infarction for 2015-2019 (stenting)

\begin{tabular}{|c|c|c|c|c|c|}
\hline \multicolumn{6}{|c|}{ Stenting } \\
\hline & 2015 & 2016 & 2017 & 2018 & 2019 \\
\hline Total & 27 & 136 & 228 & 355 & 504 \\
\hline Alfa-Medica LLC & 27 & 136 & 228 & 334 & 338 \\
\hline
\end{tabular}

Sources: developed by the authors.

As part of the «Regional target program for the development of reperfusion, cardiac surgery and rehabilitation care in Sumy region for 2018-2022» two more departments of reperfusion cardiac surgery were opened in the region - «Sumy Regional Clinical Hospital» and KNP «Clinical Hospital № 1 of Sumy City Council». It made possible to improve the quality of medical care for patients with ACS.

Within the mechanism of public-private partnership, in order to provide quality medical care with material, technical and human resources of the private medical enterprise «Alfa-Medica» by carrying out 
invasive medical care for patients with acute cardiac syndrome in 2015-2019 there is the tendency for reduction the mortality of population and its disability.

The profit received by the Municipal Non-Profit Enterprise of the Sumy Regional Council in Sumy Regional Cardiology Dispensary from the rent of the premises of ALFA-MEDICA LLC fluctuates annually within 100 thousand hrn (2020 - 104.2 thousand hrn).

While the development and implementation the strategy of the public-private partnership projects in the field of health care in Ukraine the priority of state and regional interests in solving medical and social problems should be taken into account.

Conclusions. As the result of the investigation related with medical and social issues the imperfection of the existing system of public-private partnership in the field of health care in Ukraine and Sumy region in particular was revealed. Based on the analysis of the implementation of PPP projects in Sumy region, the theoretical generalization and ways for optimizing the provision of quality medical care for patients with acute cardiac syndrome through partnership with a private medical institution, including its logistical capabilities and human resources in the new social conditions and during the restructuring of the health care system in Ukraine, were presented.

1. The existing system of public-private partnership in the field of health care needs further improvement at the level of regulatory support.

2. The mechanism of public-private partnership requires its wider implementation for state and municipal health care institutions in order to use the capabilities of private medical institutions to improve the quality of medical care.

3. In the structure of prevalence and mortality of the population of Sumy region, the leading position is occupied by diseases of the circulatory system, including acute cardiac syndrome.

4. During 2015-2017, all interventions for patients with ACS were performed exclusively on the equipment of Alfa-Medica LLC, as only this medical institution had a single angiograph in Sumy region.

5. Advantages for use the mechanism of public-private partnership, that consider quality medical care provided with material, technical and human resources of the private medical enterprise «AlfaMedica» within providing invasive medical care to patients with acute cardiac syndrome in the period 20152019, resulted in reduction of mortality and disability indicators.

6. The Regional Target Program for the Development of Reperfusion, Cardiac Surgery and Rehabilitation Care is operating in Sumy Oblast for the period of 2018-2022 years. It has made possible to open two new departments of interventional cardiac care and improve the providing of the interventional cardiac care for patients with acute cardiac syndrome.

Author Contributions: conceptualization, Y. H. and I. M.; methodology, Y. H. and P. S.; software, Y. H.; validation, P. S. and Y. H.; formal analysis, I. M.; investigation, I. M.; data curation, Y. H.; writingoriginal draft preparation, I. M.; writing-review and editing, Y. H. and I. M.; visualization, I. M.; supervision, Y. H.; project administration, Y. H.

Funding: This research received no external funding.

\section{References}

Bezbach, N. (2011). Problems of functioning of mechanisms for state regulation of partnership relations in Ukraine. State and Regions, 2, 92-96. [Google Scholar]

Brailovsky, I. (2013). Public-private partnership as an instrument for meeting social needs. Scientific Notes of Ostroh Academy National University, «Economics» Series, (23), 11-14. [Google Scholar]

Kyiv Regional Target Program «Prevention and Treatment of Cardiovascular Diseases for 2017-2019». Retrieved from [Link]

Law of Ukraine «On Concession» dated 16.07.1999 № 997-XIV. Retrieved from [Link]

Law of Ukraine «On the Public-Private Partnership» dated 01.07.2010 № 2404VI. Retrieved from [Link]

Law of Ukraine «On state financial guarantees of medical services» dated 19.10.2017 №2168 -VIII. Retrieved from [Link] 
Ministry of Health of Ukraine. (2018). Guidelines for the implementation of public-private partnership projects in the field of health care Retrieved from [Link]

Ministry of Infrastructure of Ukraine. (n.d.). Public-Private Partnerships. Retrieved from [Link

Musgrove, P. (1996). Public and Private Roles in Health: Theory and Financing Patterns. HNP discussion paper series; World Bank, Washington, DC. Retrieved from [Link]

Order of the Cabinet of Ministers of Ukraine «On approval of the Concept of public-private partnership in Ukraine for 20132018» № 739. Retrieved from [Link]

Order of the Ministry of Economic Development and Trade of Ukraine «Some issues of analysis of the effectiveness of publicprivate partnership» № 255. Retrieved from [Link]

Order of the State Property Fund of Ukraine «On approval of the Technological map of the administrative service for registration of state property concession agreements» dated 29.04.2013 № 591 (2013a). Retrieved from [Link]

Resolution of the Cabinet of Ministers of Ukraine «On approval of the Procedure for providing a private partner to a public partner with information on the implementation of an agreement concluded within the framework of a public-private partnership» № 81, dated 09.02.2011. Retrieved from [Link]

Resolution of the Cabinet of Ministers of Ukraine «On Approval of the Procedure for Providing State Support to Public-Private Partnerships» № 279, dated 17.03.2011. Retrieved from [Link]

Resolution of the Cabinet of Ministers of Ukraine «On approval of the Procedure for replacement of a private partner under an agreement concluded within the framework of a public-private partnership» № 298, dated 26.04.2017. Retrieved from [Link]

U.S. Agency for International Development. [Link]

Vynnytsky, B., Lendiel, M., Onyschuk, B., \& Segvari, P. (2008). Experience and prospects of implementation of public-private partnerships in Ukraine and abroad. Kyiv, «KIS». $146 \mathrm{p}$.

World Health Organization. Health systems: key expected results. Retrieved from [Link]

Юлія Гуменна, Ph.D., Сумський державний університет, Україна

Irop Марцовенко, к.е.н., головний лікар, Сумський обласний клінічний кардіологічний диспансер, Україна

Пауліна Сровналікова, Ph.D., Університет Олександра Дубчека в Тренчині, Словаччина

Реформування медичної галузі України: аспекти державно-приватного партнерства

Дана стаття присвячена дослідженню особливостей впровадження державно-приватного партнерства як ключової форми інвестування фінансових ресурсів в сферу надання медичних послуг в Україні. Метою дослідження $є$ дослідження напрямів державно-приватного партнерства при фінансуванні медичної галузі України на прикладі Сумського обласного клінічного кардіологічного диспансеру. В даній статті досліджені сучасні концепції й моделі державно-приватного партнерства в галузі охорони здоров'я та особливості їх практичного впровадження. Проаналізована нормативно-правова база державно-приватного партнерства в системі охорони здоров'я України. Методичне забезпечення дослідження включає використання методу системного аналізу, синтезу та наукової абстракції, структурно-логічного, порівняльного та статистичного аналізу, та ретроспективного методу. Результати проведеного дослідження дозволили: визначити суб'єктну та об'єктну компоненти державно-приватного партнерства; проаналізувати зарубіжний досвід формування моделей комбінації фрункцій, які передаються приватному партнеру з боку державних установ; обгрунтувати особливості впровадження партнерства в умовах медичної реформи; дослідити практичний досвід впровадження проектів державноприватного партнерства у сфері охорони здоров'я в Україні; надати медико-соціальне обірунтування покращання якості надання медичної допомоги хворим на гострий коронарний синдром на основі моделі державно-приватного партнерства; виявити бар'єри, що перешкоджають впровадженню державно-приватного партнерства в галузі охороні здоров'я на сучасному етапі розвитку медичної галузі України; удосконалити використання моделі державно-приватного партнерства на основі договору про спільну діяльність між комунальним закладом охорони здоров'я та приватною структурою 3 метою покращання якості надання невідкладної медичної допомоги хворим з гострими коронарними станами. В роботі констатовано, що при використанні можливостей механізму державно-приватного партнерства, залучивши до надання якісної медичної допомоги матеріально-технічні та кадрові ресурси приватного медичного підприємства «Альфа- Медика» шляхом надання інвазивної медичої допомоги хворим на гострий кардіальний синдром в період 2015-2019 рр. вдалося досягти зниження показників смертності населення та його інвалідності. В дослідженні надані рекомендації щодо врахування при створенні стратегії впровадження та реалізації проектів державно-приватного партнерства у сфері охорони здоров'я в Україні як державних, так і регіональних інтересів при вирішенні медико-соціальних проблем шляхом розробки і реалізації відповідних програм.

Ключові слова: державно-приватне партнерство, реформування медичної галузі, державний партнер, приватний партнер, гостра кардіальна патологія, ішемічна хвороба серця. 